\title{
Arsenic trioxide and bortezomib interact synergistically to induce apoptosis in chronic myelogenous leukemia cells resistant to imatinib mesylate through Bcr/Abl-dependent mechanisms
}

\author{
WENBIN XU ${ }^{1}$, WEI WEI $^{2}$, QING YU ${ }^{1}, \mathrm{CHAO}^{1}, \mathrm{CHENJING} \mathrm{YE}^{1}, \mathrm{YINGLI} \mathrm{WU}^{2}$ and HUA YAN ${ }^{1,3}$ \\ ${ }^{1}$ Exclusive Medical Care Center, Rui-Jin Hospital; ${ }^{2}$ Department of Pathophysiology, \\ Key Laboratory of Cell Differentiation and Apoptosis of Chinese Ministry of Education; \\ ${ }^{3}$ Department of Hematology, Rui-Jin Hospital, Shanghai Jiao-Tong University \\ School of Medicine, Shanghai 200025, P.R. China
}

Received October 12, 2013; Accepted April 28, 2014

DOI: $10.3892 / \mathrm{mmr} .2014 .2333$

\begin{abstract}
Arsenic trioxide $\left(\mathrm{As}_{2} \mathrm{O}_{3}\right)$ and the proteasome inhibitor bortezomib (BTZ) have been used successfully to treat acute promyelocytic leukemia and multiple myeloma. Their synergistic effects with other anticancer drugs have been widely studied. In this study, interactions between $\mathrm{As}_{2} \mathrm{O}_{3}$ and BTZ were examined in imatinib-resistant $\mathrm{Bcr} / \mathrm{Abl}^{+}$ (K562r) cells. Co-treatment of K562r cells with subtoxic concentrations of $\mathrm{As}_{2} \mathrm{O}_{3}(2 \mu \mathrm{M})$ and BTZ $(24 \mathrm{nM})$ resulted in a synergistic enhancement in growth inhibition and apoptosis, as demonstrated by increased annexin V staining. These events were associated with activation of protein kinase $C \delta$, poly ADP-ribose polymerase cleavage and caspase-3 activation, along with downregulation of Bcr/Abl mRNA and Bcr/Abl protein expression levels during apoptosis. In addition, reactive oxygen species were downregulated during combined treatment in K562r cells. Collectively, these findings suggest that BTZ and $\mathrm{As}_{2} \mathrm{O}_{3}$ act synergistically to induce apoptosis in $\mathrm{K} 562 \mathrm{r}$ cells. Therefore, further studies are required to assess the potential of $\mathrm{BTZ}$ and $\mathrm{As}_{2} \mathrm{O}_{3}$ combinatory treatment of chronic myeloid leukemia, particularly using imatinib-resistant $\mathrm{Bcr} / \mathrm{Abl}^{+}$clones.
\end{abstract}

\section{Introduction}

Chronic myelogenous leukemia (CML) is a myeloproliferative disorder of the bone marrow stem cells characterized by genetic translocation between chromosomes 9 and 22. This translocation results in the fusion of $\mathrm{Bcr}$ on chromosome 22 with $\mathrm{Abl}$

Correspondence to: Dr Hua Yan, Department of Hematology, Rui-Jin Hospital, Shanghai Jiao-Tong University School of Medicine, 197 Ruijin Er Road, Shanghai 200025, P.R China

E-mail: yanhua_candy@163.com

Key words: arsenic trioxide, bortezomib, chronic myelogenous leukemia, resistant, apoptosis on chromosome 9, leading to the expression of the Bcr/Abl fusion oncoprotein. This fusion protein exhibits constitutively active kinase activity (1), transducing signals to a variety of downstream survival pathways, including the mitogen-activated protein kinase kinase/extracellular signal-regulated kinase cascade, Akt, and the signal transducers and activators of transcription (STATs) and nuclear factor $\kappa \mathrm{B}(\mathrm{NF}-\kappa \mathrm{B})$ pathways (2-4). A number of anti-apoptotic proteins, such as B-cell lymphoma extra large, are upregulated as a result of the activation of these pathways. Collectively, these events provide $\mathrm{Bcr} / \mathrm{Abl}^{+}$cells with a survival advantage over normal cells, due to their reduced capacity to undergo apoptosis. Furthermore, $\mathrm{Bcr} / \mathrm{Abl}^{+}$cells have exhibited varying degrees of resistance towards conventional cytotoxic drugs (5-7), until the recent clinical application of imatinib mesylate $\left(\right.$ Gleevec ${ }^{\circledR}$, STI-571). Imatinib has been widely demonstrated to be effective in the treatment of CML through inhibition of the tyrosine kinase activity of Bcr/Abl. However, acquired resistance to imatinib can occur through various mechanisms, thereby leading to continued disease progression. Thus, the development of alternative approaches to the treatment of $\mathrm{CML}$ is required.

Bortezomib (BTZ), also known as Velcade ${ }^{\circledR}$ or PS-341, has been shown to act as an inducer of apoptosis in multiple myeloma cells. BTZ exerts its effects through a number of signaling cascades, predominantly the $\mathrm{NF}-\kappa \mathrm{B}$ pathway, ultimately inducing apoptosis and thereby reversing drug resistance and improving prognosis $(8,9)$. The administration of BTZ as a combination treatment with other agents has been widely investigated; the cyclin-dependent kinase inhibitor flavopiridol and the histone deacetylase inhibitor suberoylanilide hydroxamic acid have both been shown to act synergistically with BTZ to induce apoptosis in $\mathrm{Bcr} / \mathrm{Abl}^{+}$ cells $(10,11)$.

Arsenic trioxide $\left(\mathrm{As}_{2} \mathrm{O}_{3}\right)$ is a chemotherapeutic agent that acts by inducing apoptosis and differentiation and can uniquely induce complete remission in the majority of patients with acute promyelocytic leukemia (12-14). Furthermore, studies have shown that $\mathrm{As}_{2} \mathrm{O}_{3}$ alone, and in combination with other compounds, induces apoptosis and/or growth arrest in $\mathrm{Bcr} / \mathrm{Abl}^{+}$cells (15-17). However, high concentrations of $\mathrm{As}_{2} \mathrm{O}_{3}$ 
were used in these studies, and, due to the toxic nature of arsenic, its use has been limited in clinical practice. In 2007, Yan et al (18) showed that clinically achievable concentrations of $\mathrm{As}_{2} \mathrm{O}_{3}$ could act synergistically with BTZ to successfully induce apoptosis in imatinib-sensitive $\mathrm{Bcr} / \mathrm{Abl}^{+}$(K562) cells, in which protein kinase $\mathrm{C} \delta(\mathrm{PKC} \delta)$ activation played a critical role.

This study aimed to investigate the effects of the combination of $\mathrm{As}_{2} \mathrm{O}_{3}$ and $\mathrm{BTZ}$ on apoptosis in imatinib-resistant $\mathrm{Bcr} / \mathrm{Abl}^{+}$cells and to determine whether this combinatory approach warranted further investigation as a potential therapeutic strategy for the treatment of CML, particularly for cases exhibiting imatinib resistance.

\section{Materials and methods}

Reagents. Imatinib (STI571) was purchased from Selleck Chemicals (Houston, TX, USA), prepared as a $1 \mathrm{mM}$ stock solution in dimethyl sulfoxide and stored at $-20^{\circ} \mathrm{C}$. BTZ (Millennium Pharmaceuticals Inc., Cambridge, MA, USA) was dissolved in phosphate-buffered saline (PBS) and stored at $-20^{\circ} \mathrm{C}$ until use. $\mathrm{As}_{2} \mathrm{O}_{3}$ (Sigma, St. Louis, MO, USA) was dissolved in $1.0 \mathrm{~N} \mathrm{NaOH}$ and then diluted to $1 \mathrm{mM}$ with PBS.

Cell culture and viability assay. K562 and K562r cells (provided by Professor J.V. Melo, Department of Haematology, Imperial College of London, London, UK) were cultured in RPMI-1640 media supplemented with $10 \%$ heat-inactivated fetal bovine serum (Gibco-BRL, Gaithersburg, MD, USA) in a humidified atmosphere with $5 \% \mathrm{CO}_{2}$ at $37^{\circ} \mathrm{C}$. $\mathrm{K} 562 \mathrm{r}$ cells were cultured in $1 \mu \mathrm{M}$ imatinib to maintain drug-resistance. Cell viability and inhibition of cell growth were estimated using a Cell Counting kit 8 (Dojindo Laboratories, Kumamoto, Japan).

Apoptosis assessment. Apoptosis was measured using a fluorescein isothiocyanate (FITC) Annexin V Apoptosis Detection kit (BD Biosciences, Franklin Lakes, NJ, USA) in accordance with the manufacturer's instructions. Following treatment with $\mathrm{As}_{2} \mathrm{O}_{3}$ and/or BTZ, $1 \times 10^{5} \mathrm{~K} 562 \mathrm{r}$ cells were collected, washed with cold PBS and resuspended with binding buffer. A total of $5 \mu \mathrm{l}$ annexin V-FITC was added and cells were incubated for $5 \mathrm{~min}$ in the dark. Following incubation, $10 \mu \mathrm{l}$ propidium iodide was added and the samples were incubated for an additional 3 min. Binding buffer $(400 \mu \mathrm{l})$ was then added and cells were analyzed by flow cytometry.

Western blot analysis. Equal amounts of protein were loaded on $8-14 \%$ SDS-polyacrylamide gels, subjected to SDS-PAGE and transferred to nitrocellulose membranes (Amersham Pharmacia Biotech, Amersham, UK). The blots were stained with $0.2 \%$ Ponceau $S$ red to ensure equal protein loading. Following blocking with 5\% nonfat milk in PBS, the membranes were probed with primary antibodies targeting c-Abl, PKC $\delta$, poly (ADP-ribose) polymerase (PARP) (Santa Cruz Biotechnology, Inc., Santa Cruz, CA, USA) and cleaved caspase-3 (Cell Signaling Technology, Inc., Beverly, MA, USA). Membranes were subsequently incubated with horseradish peroxidase (HRP)-linked secondary antibodies (Cell Signaling Technology, Inc.) and the signal was detected using a chemiluminescence Phototope ${ }^{\circledR}$-HRP kit (Cell Signaling
Technology, Inc.). Blots were stripped and reprobed with a mouse anti- $\beta$-actin monoclonal antibody (Oncogene, San Diego, CA, USA) as a loading control.

Quantitative polymerase chain reaction ( $q P C R)$ analysis of $B c r / A b l$ mRNA. Total RNA was isolated by TRIzol ${ }^{\mathrm{TM}}$ reagent (Invitrogen Life Technologies, Carlsbad, CA, USA) and RNA was treated with DNase (Promega Corp., Madison, WI, USA). Complementary DNA was synthesized according to the manufacturer's instructions. The analysis of $\mathrm{Bcr} / \mathrm{Abl}$ and $\beta$-actin was performed by qPCR using SYBR Green PCR Master Mix reagents (Applied Biosystems, Foster City, CA, USA) using an ABI PRISM 7900 system (Applied Biosystems). The specific primers used for detecting p210 Bcr/Abl were as follows: Forward primer (5'-CTGGCCCAACGATGGCGA-3') and reverse primer (5'-CACTCAGACCCTGAGGCTCAA-3'). Primers were synthesized by Sangon Biotechnology (Shanghai, China).

Measurement of reactive oxygen species (ROS). Cells were incubated with either $\mathrm{As}_{2} \mathrm{O}_{3}$, BTZ or the two in combination for the indicated times. Following incubation, cells were washed twice with PBS and treated with $10 \mu \mathrm{M} 2^{\prime}, 7^{\prime}$-dichlorodihydrofluorescein diacetate (Molecular Probes ${ }^{\circledR} /$ Invitrogen Life Technologies) for $30 \mathrm{~min}$ at $37^{\circ} \mathrm{C}$, in the dark. Cells were then washed with PBS once. Red fluorescence was detected by fluorescence-activated cell sorting at an excitation wavelength of $485 \mathrm{~nm}$ and an emission wavelength of $535 \mathrm{~nm}$.

Statistical analysis. All experiments were repeated in triplicate. The SPSS 11.0 (SPSS Inc., Chicago, IL, USA) software package was used for statistical analysis. $\mathrm{P}<0.05$ was considered to indicate a statistically significant difference. Results are presented as the mean \pm standard deviation.

\section{Results}

K562r cells are more resistant than $K 562$ cells to imatinib treatment. In order to determine the resistance characteristics of K562r cells, K562 (imatinib-sensitive) or K562r (imatinib-resistant) cells were incubated with varying concentrations of imatinib. Of note, $0.5 \mu \mathrm{M}$ imatinib induced $50 \%$ inhibition of $\mathrm{K} 562$ cell growth, whereas up to $10 \mu \mathrm{M}$ imatinib was required to inhibit 50\% cell growth in K562r cells (Fig. 1A and B). Western blot analysis showed that $1 \mu \mathrm{M}$ imatinib caused the downregulation of Bcr/Abl protein expression in $\mathrm{K} 562$ cells, whereas $25 \mu \mathrm{M}$ imatinib was required to observe measurable downregulation in K562r cells (Fig. 1C and D).

BTZ synergistically interacts with $\mathrm{As}_{2} \mathrm{O}_{3}$ to induce apoptosis in K562r cells. Treatment with either BTZ or $\mathrm{As}_{2} \mathrm{O}_{3}$ alone inhibited cell growth in $\mathrm{K} 562 \mathrm{r}$ cells in a dose- and time-dependent manner (Fig. 2A and B). To evaluate the potential synergistic effects of these two agents, BTZ and $\mathrm{As}_{2} \mathrm{O}_{3}$ were used at concentrations of $24 \mathrm{nM}$ and $2 \mu \mathrm{M}$, respectively, the individual half maximal concentration $\left(\mathrm{IC}_{50}\right)$ of these agents in the inhibition of K562r cell growth. Neither of these concentrations elicited significant apoptosis-inducing effects. After $24-48 \mathrm{~h}$ of combined incubation with BTZ and $\mathrm{As}_{2} \mathrm{O}_{3}$, growth inhibition and apoptosis induction were significantly enhanced in $\mathrm{K} 562 \mathrm{r}$ 
A

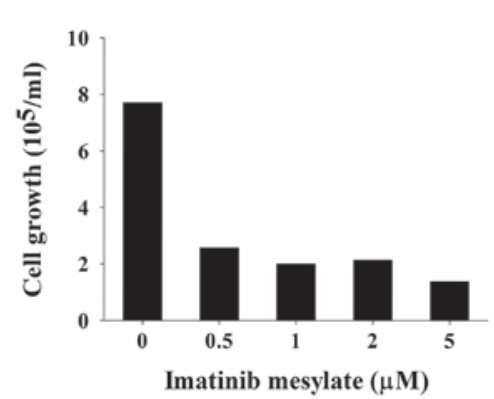

C

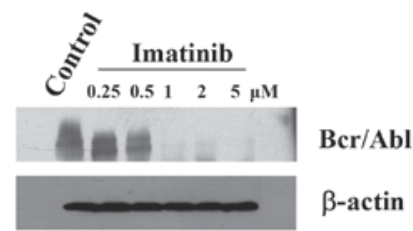

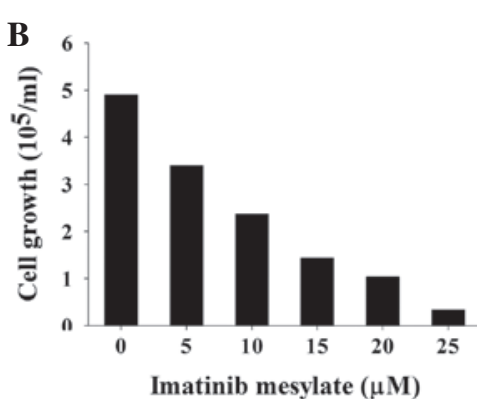

D

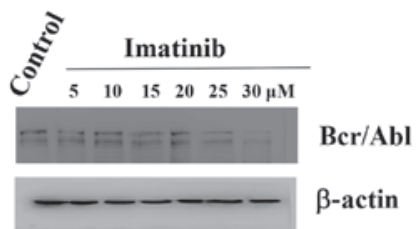

Figure 1. K562r cells are more resistant to imatinib treatment than K562 cells. Cells were exposed to the indicated concentrations of imatinib mesylate for $48 \mathrm{~h}$ and (A and B) cell growth and (C and D) Bcr/Abl protein expression in (A and C) K562 and (B and D) K562r cells were measured.

A

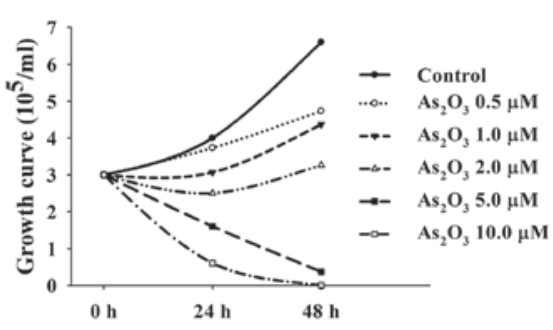

C

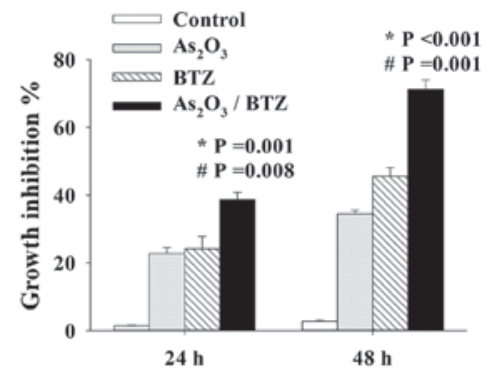

B

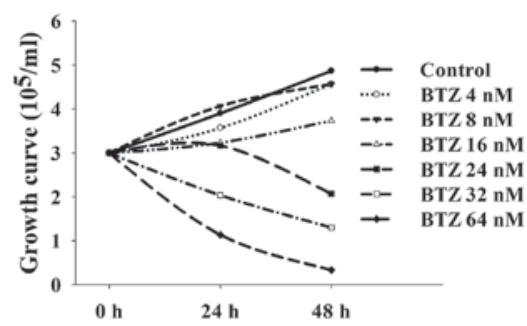

D

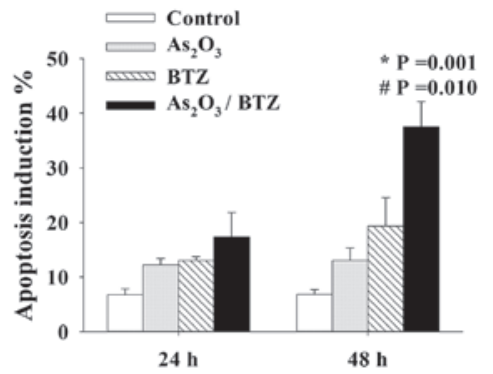

Figure 2. BTZ and $\mathrm{As}_{2} \mathrm{O}_{3}$ synergistically induce growth arrest and apoptosis of K562r cells. K562r cells were exposed to the indicated concentrations of (A) $\mathrm{As}_{2} \mathrm{O}_{3}$ and (B) BTZ for $48 \mathrm{~h}$ and the growth curves were measured. A total of $2 \mu \mathrm{M} \mathrm{As}_{2} \mathrm{O}_{3}$ and/or $24 \mathrm{nM}$ BTZ were selected for combined treatment, and the (C) growth inhibition and (D) annexin $\mathrm{V}^{+}$apoptotic cells were measured. Error bars represent standard deviation, from three independent experiments. "P-value versus $\mathrm{As}_{2} \mathrm{O}_{3}$ treatment; ${ }^{*} \mathrm{P}$-value versus BTZ treatment. $\mathrm{As}_{2} \mathrm{O}_{3}$, arsenic trioxide; BTZ, bortezomib.

cells as compared with those administered a single treatment $(\mathrm{P}<0.05)$ (Fig. 2C and D).

Combined treatment with $\mathrm{BTZ}$ and $\mathrm{As}_{2} \mathrm{O}_{3}$ results in enhanced caspase-3 activation and PARP and PKC $\delta$ cleavage. Western blot analysis was performed to assess apoptosis-associated events during combined treatment with BTZ and $\mathrm{As}_{2} \mathrm{O}_{3}$ in $\mathrm{K} 562 \mathrm{r}$ cells. Treatment with $24 \mathrm{nM}$ BTZ or $2 \mu \mathrm{M} \mathrm{As}_{2} \mathrm{O}_{3}$ alone resulted in only minimal effects, whereas combined treatment with BTZ and $\mathrm{As}_{2} \mathrm{O}_{3}$ for up to $48 \mathrm{~h}$ resulted in a significant increase in caspases-3 activation, as well as enhanced PARP and PKC $\delta$ cleavage (Fig. 3).

Combined treatment with $\mathrm{BTZ}$ and $\mathrm{As}_{2} \mathrm{O}_{3}$ downregulates $B c r / A b l$ mRNA and protein expression. The Bcr/Abl kinase can inhibit apoptosis through multiple mechanisms, leading $\mathrm{Bcr} / \mathrm{Abl}^{+}$cells to develop resistance to apoptosis induced by conventional agents (5-7). In the present study, the effects of $24 \mathrm{nM}$ BTZ and/or $2 \mu \mathrm{M} \mathrm{As}_{2} \mathrm{O}_{3}$ on Bcr/Abl mRNA and protein expression were examined. The results showed that single treatment with either BTZ or $\mathrm{As}_{2} \mathrm{O}_{3}$ alone could decrease $\mathrm{Bcr} / \mathrm{Abl} \mathrm{mRNA}$ and protein expression to a moderate extent; however, combined treatment with the two agents resulted in a significant decrease in Bcr/Abl expression in $\mathrm{K} 562 \mathrm{r}$ cells $(\mathrm{P}<0.01)$, most markedly after $48 \mathrm{~h}$ of incubation (Fig. 4A and $\mathrm{B}$ ). This effect was further confirmed by the Bcr/Abl protein downregulation analyzed by western blotting.

BTZ enhances $\mathrm{As}_{2} \mathrm{O}_{3}$-induced downregulation of ROS in K562r cells. $\mathrm{As}_{2} \mathrm{O}_{3}$ has been reported to exert 


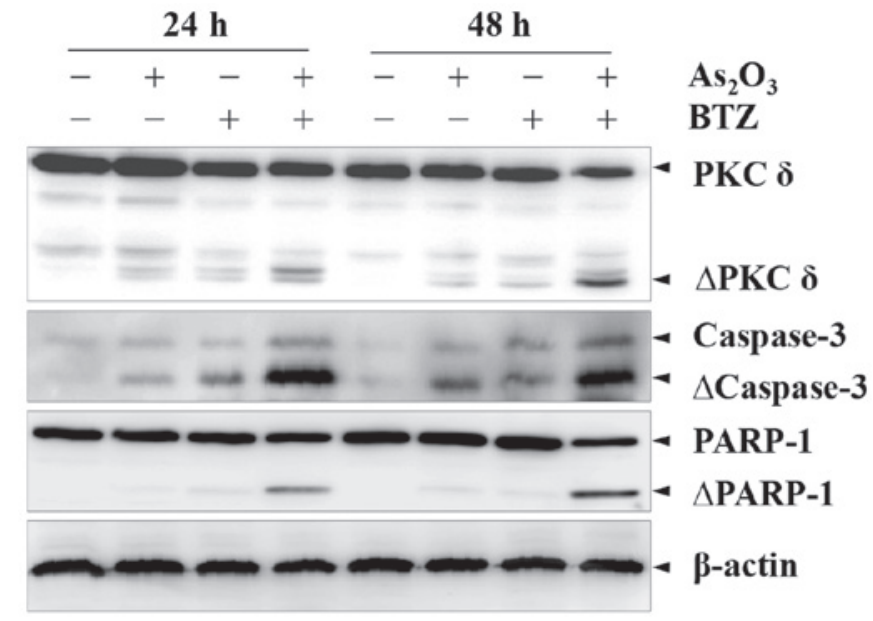

Figure 3. BTZ and $\mathrm{As}_{2} \mathrm{O}_{3}$ synergistically enhance caspase-3 activation as well as PKC $\delta$ and PARP cleavage in K562r cells. K562r cells were exposed to $24 \mathrm{nM} \mathrm{BTZ}$ and/or $2 \mu \mathrm{M} \mathrm{As}_{2} \mathrm{O}_{3}$ for $48 \mathrm{~h}$. The indicated proteins were detected by western blotting with $\beta$-actin as loading control. PARP, poly ADP-ribose polymerase; $\mathrm{PKC} \delta$, protein kinase $\mathrm{C} \delta ; \mathrm{As}_{2} \mathrm{O}_{3}$, arsenic trioxide; BTZ, bortezomib.

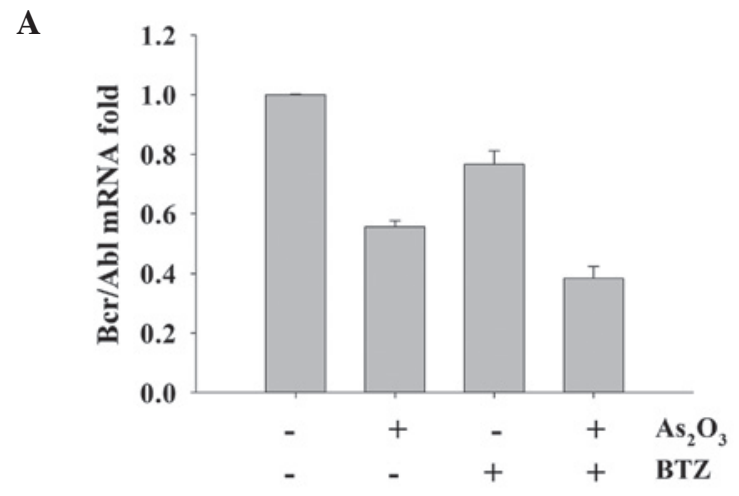

B

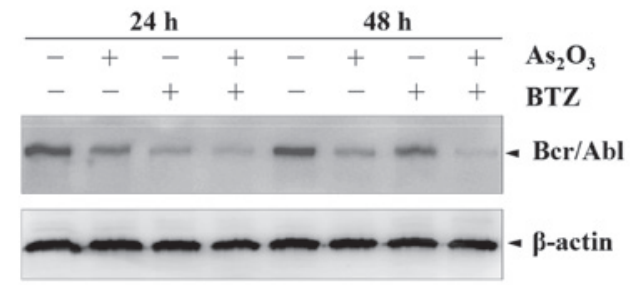

Figure 4. BTZ and $\mathrm{As}_{2} \mathrm{O}_{3}$ synergistically downregulate the expression of $\mathrm{Bcr} / \mathrm{Abl}$ mRNA as well as Bcr/Abl protein levels. K562 $\mathrm{r}$ cells were exposed to $24 \mathrm{nM} \mathrm{BTZ}$ and/or $2 \mu \mathrm{M} \mathrm{As}_{2} \mathrm{O}_{3}$ for 24-48 h. (A) Quantitative polymerase chain reaction was used to detect the Bcr/Abl mRNA level, expressed as the fold-change compared with the control level. (B) Western blotting was used to detect $\mathrm{Bcr} / \mathrm{Abl}$ protein expression. $\beta$-actin was used as a loading control. Error bars represent standard deviation, from three independent experiments. $\mathrm{As}_{2} \mathrm{O}_{3}$, arsenic trioxide; BTZ, bortezomib.

pro- or anti-apoptotic effects via manipulating cellular oxidative stress, whilst BTZ is considered to be an inducer of ROS (19-21). The effects of $\mathrm{As}_{2} \mathrm{O}_{3}$ and/or BTZ on ROS production in $\mathrm{K} 562 \mathrm{r}$ cells were next investigated. The results showed that treatment with $\mathrm{As}_{2} \mathrm{O}_{3}$ alone exhibited a marginal decrease in ROS production, whilst that with BTZ elicited an increase in ROS levels. Of note, although $\mathrm{As}_{2} \mathrm{O}_{3}$ and BTZ exerted opposing effects, combined treatment with both

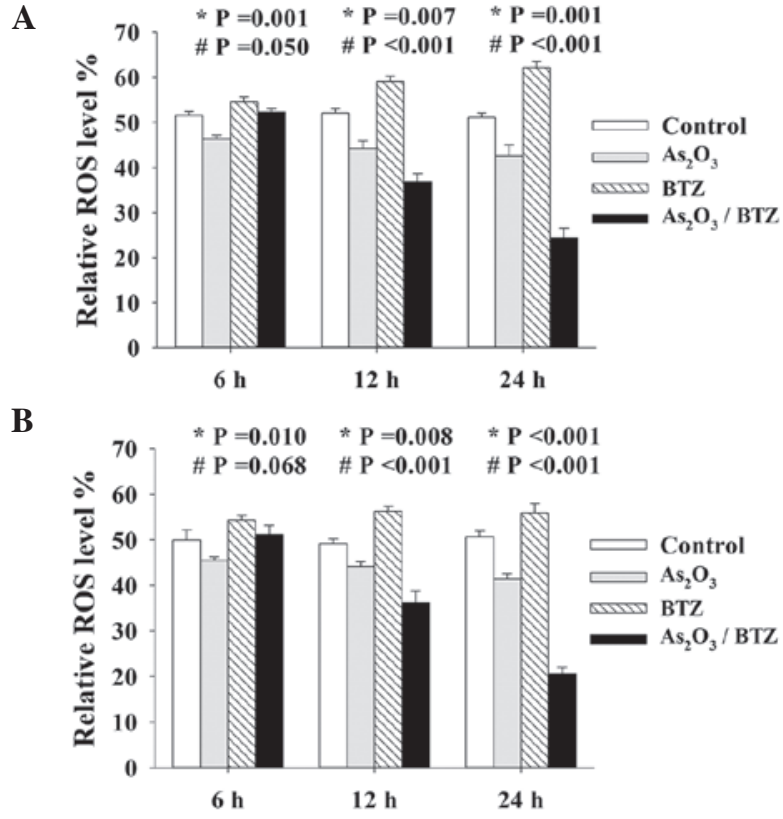

Figure 5. ROS production is significantly downregulated in $\mathrm{BTZ} / \mathrm{As}_{2} \mathrm{O}_{3}$-treated $\mathrm{Bcr}_{\mathrm{Abl}}{ }^{+}$cells. (A) K562r cells were exposed to $24 \mathrm{nM} \mathrm{BTZ}$ and/or $1 \mu \mathrm{M}$ $\mathrm{As}_{2} \mathrm{O}_{3}$ for 6,12 and $24 \mathrm{~h}$ and the relative ROS level was measured using direct fluorescent antibody staining. (B) A parallel experiment was performed in K562 cells. "P-value versus $\mathrm{As}_{2} \mathrm{O}_{3}$ treatment; ${ }^{~} \mathrm{P}$-value versus BTZ treatment. Error bars represent standard deviation, from three independent experiments. $\mathrm{As}_{2} \mathrm{O}_{3}$, arsenic trioxide; BTZ, bortezomib; ROS, reactive oxygen species.

agents significantly downregulated ROS production. Parallel experiments were performed in K562 cells and comparable results were produced (Fig. 5A and B).

\section{Discussion}

Despite the success of imatinib, the emergence of drug resistance and disease progression in CML remains a continuing problem (22). In the present in vitro study, it was found that the $\mathrm{IC}_{50}$ of imatinib in $\mathrm{K} 562 \mathrm{r}$ cells was up to 20 -fold greater than that in K562 cells and clinically unachievable concentrations of up to $20 \mu \mathrm{M}$ were required to downregulate $\mathrm{Bcr} / \mathrm{Abl}$ protein. Thus, the identification of alternative drugs or targets is of great importance. It has been suggested that, instead of inhibiting the tyrosine kinase activity, targeting the signaling pathways downstream of $\mathrm{Bcr} / \mathrm{Abl}$ or downregulating $\mathrm{Bcr} / \mathrm{Abl}$ expression could be an effective strategy to overcome imatinib resistance (23).

Following the success of BTZ in the treatment of myeloma, proteasome inhibitors have gained interest as novel treatment strategies for cancer. As summarized by a number of studies $(10,11,18,24)$, proteasome inhibitors, including BTZ, may exhibit anti-leukemic activities when used alone and may increase the sensitivity of cancer cells to various anti-cancer agents, including flavopiridol, histone deacetylase inhibitors and $\mathrm{As}_{2} \mathrm{O}_{3}$. The combination treatment of $\mathrm{As}_{2} \mathrm{O}_{3}$ and BTZ has been widely reported to induce apoptosis in numerous leukemia cell lines $(18,25-27)$. Among these studies, a report by Yan et al (18) showed that $\mathrm{As}_{2} \mathrm{O}_{3}$ and BTZ interacted synergistically to enhance apoptosis in imatinib-sensitive K562 cells, predominantly through $\mathrm{PKC} \delta$ activation and decreased $\mathrm{NF}-\kappa \mathrm{B}$ activity. In the present study, the data showed that clinically 
achievable concentrations of BTZ and $\mathrm{As}_{2} \mathrm{O}_{3}$ could synergistically inhibit cell growth and induce apoptosis in K562r cells that were resistant to imatinib treatment. Thus, these data support the potential use of this combinatory therapy in the treatment of imatinib-resistant leukemia.

The caspase cascade is a protease system that directly facilitates apoptosis. Activation of caspase-3, the endpoint of this cascade, is critical in cleaving numerous substrates, including the repair enzyme PARP, leading to DNA strand breaks and eventually apoptosis. Caspase-3-mediated cleavage of PARP has been shown to induce apoptosis in various malignant cell lines, including Caco-2 colon cancer cells (28). Consistent with previous reports, the present study also identified that the serial activity of caspases was involved in inducing apoptosis in combined treatment with BTZ and $\mathrm{As}_{2} \mathrm{O}_{3}$ in CML cells, further supporting the use of this treatment in chemotherapies for CML (18,26-27).

The Bcr/Abl kinase plays a key role in the pathogenesis of $\mathrm{Bcr} / \mathrm{Abl}^{+}$malignancies by blocking apoptosis through multiple pathways, including NF- $\mathrm{B}$, Akt and STAT signaling cascades (29). As reported both in vitro and in vivo, the overexpression of Bcr/Abl kinase represents a major mechanism of resistance to imatinib $(22,30)$. Wei et al $(31)$ reported that alantolactone could significantly induce apoptosis in K562r cells and that this mechanism involved the knockdown of $\mathrm{Bcr} / \mathrm{Abl}$ protein expression, resulting in increased apoptosis. Thus, $24 \mathrm{nM} \mathrm{BTZ}$ and $2 \mu \mathrm{M} \mathrm{As}_{2} \mathrm{O}_{3}$ were tested in combination in $\mathrm{K} 562 \mathrm{r}$ cells and the expression levels of Bcr/Abl were analyzed. Of note, while each agent alone minimally affected the expression of $\mathrm{Bcr} / \mathrm{Abl}$, combined treatment led to a marked downregulation of $\mathrm{Bcr} / \mathrm{Abl}$ mRNA and protein, thus providing important insights into the mechanisms through which these drugs exert their effects.

ROS act as important regulators of apoptosis through numerous signaling pathways (19). A previous study reported that $\mathrm{As}_{2} \mathrm{O}_{3}$ and $\mathrm{BTZ}$ alone or in combination with other agents could induce ROS production and subsequent apoptosis in several cell lines, including NB4 cells (20). However, certain studies have shown contradictory results, such as a study by Stepnik et al (21), which showed that $5 \mu \mathrm{M} \mathrm{As}{ }_{2} \mathrm{O}_{3}$ induced $>20$-fold increase in the generation of ROS in HL-60 cells after $6 \mathrm{~h}$ of exposure, whereas a $35 \%$ decrease was noted in K562 cells under the same conditions. This indicated that the ROS response in cells was strongly dependent on the cell origin, concentration of drugs, time of exposure and other parameters (21). Additionally, the $\mathrm{Bcr} / \mathrm{Abl}$ kinase is known to enhance ROS production in certain Bcr/Abl-expressing hematopoietic cells and imatinib could effectively reduce ROS production during apoptosis (32-34). In the present study, the effects of the $\mathrm{BTZ} / \mathrm{As}_{2} \mathrm{O}_{3}$ combination on ROS production at 6,12 and 24 h of incubation were investigated. Of note, $2 \mu \mathrm{M} \mathrm{As} \mathrm{O}_{3}$ moderately decreased ROS levels, while $20 \mathrm{nM}$ BTZ had only a minor promoting effect on ROS levels; however, the combined treatment markedly downregulated ROS production in a time-dependent manner. These data showed that BTZ/As $\mathrm{O}_{3}$ treatment could directly reduce ROS production in $\mathrm{K} 562 \mathrm{r}$ cells and that $\mathrm{Bcr} / \mathrm{Abl}$ downregulation further enhanced this effect.

Collectively, this study showed that BTZ and $\mathrm{As}_{2} \mathrm{O}_{3}$ synergistically induced apoptosis in $\mathrm{Bcr} / \mathrm{Abl}^{+} \mathrm{K} 562 \mathrm{r}$ cells via caspase-3 activation and downregulation of Bcr/Abl kinase; reduced ROS production appeared to be involved in the underlying mechanism. These findings indicate that combined treatment of BTZ and $\mathrm{As}_{2} \mathrm{O}_{3}$ may be a potential therapeutic regimen for the treatment of imatinib-resistant CML.

\section{Acknowledgements}

This study was supported in part by the National Natural Science Foundation (grant nos. 81170509 and 30700334). The authors would like to thank Professor J.V. Melo for kindly providing the K562 and K562r cells.

\section{References}

1. Schiffer CA, Hehlmann R and Larson R: Perspectives on the treatment of chronic phase and advanced phase CML and Philadelphia chromosome positive ALL(1). Leukemia 17: 691-699, 2003.

2. Voss J, Posern G, Hannemann JR, Wiedemann LM, Turhan AG, Poirel H, Bernard OA, Adermann K, Kardinal C and Feller SM: The leukaemic oncoproteins Bcr-Abl and Tel-Abl (ETV6/Abl) have altered substrate preferences and activate similar intracellular signalling pathways. Oncogene 19: 1684-1690, 2000.

3. Danial NN and Rothman P: JAK-STAT signaling activated by Abl oncogenes. Oncogene 19: 2523-2531, 2000.

4. Kirchner D, Duyster J, Ottmann O, Schmid RM, Bergmann L and Munzert G: Mechanisms of Bcr-Abl-mediated NF-kappaB/Rel activation. Exp Hematol 31: 504-511, 2003.

5. Bedi A, Barber JP, Bedi GC, el-Deiry WS, Sidransky D, Vala MS, Akhtar AJ, Hilton J and Jones RJ: BCR-ABL-mediated inhibition of apoptosis with delay of G2/M transition after DNA damage: a mechanism of resistance to multiple anticancer agents. Blood 86: 1148-1158, 1995.

6. Bueno-da-Silva AE, Brumatti G, Russo FO, Green DR and Amarante-Mendes GP: Bcr-Abl-mediated resistance to apoptosis is independent of constant tyrosine-kinase activity. Cell Death Differ 10: 592-598, 2003.

7. Amarante-Mendes GP, McGahon AJ, Nishioka WK, Afar DE, Witte ON and Green DR: Bcl-2-independent Bcr-Abl-mediated resistance to apoptosis: protection is correlated with up regulation of Bcl-xL. Oncogene 16: 1383-1390, 1998.

8. Cavo M: Proteasome inhibitor bortezomib for the treatment of multiple myeloma. Leukemia 20: 1341-1352, 2006.

9. Caravita T, de Fabritiis P, Palumbo A, Amadori S and Boccadoro M: Bortezomib: efficacy comparisons in solid tumors and hematologic malignancies. Nat Clinl Pract Oncol 3: 374-387, 2006.

10. Dai Y, Rahmani M, Pei XY, Dent P and Grant S: Bortezomib and flavopiridol interact synergistically to induce apoptosis in chronic myeloid leukemia cells resistant to imatinib mesylate through both Bcr/Abl-dependent and -independent mechanisms. Blood 104: 509-518, 2004.

11. Yu C, Rahmani M, Conrad D, Subler M, Dent P and Grant S: The proteasome inhibitor bortezomib interacts synergistically with histone deacetylase inhibitors to induce apoptosis in $\mathrm{Bcr} / \mathrm{Abl}^{+}$ cells sensitive and resistant to STI571. Blood 102: 3765-3774, 2003.

12. Shen ZX, Chen GQ, Ni JH, Li XS, Xiong SM, Qiu QY, Zhu J, Tang W, Sun GL, Yang KQ, Chen Y, Zhou L, Fang ZW, Wang YT, Ma J, Zhang P, Zhang TD, Chen SJ, Chen Z and Wang ZY: Use of arsenic trioxide $\left(\mathrm{As}_{2} \mathrm{O}_{3}\right)$ in the treatment of acute promyelocytic leukemia (APL): II. Clinical efficacy and pharmacokinetics in relapsed patients. Blood 89: 3354-3360, 1997

13. Chen GQ, Zhu J, Shi XG, Ni JH, Zhong HJ, Si GY, Jin XL, Tang W, Li XS, Xong SM, Shen ZX, Sun GL, Ma J, Zhang P, Zhang TD, Gazin C, Naoe T, Chen SJ, Wang ZY and Chen Z: In vitro studies on cellular and molecular mechanisms of arsenic trioxide $\left(\mathrm{As}_{2} \mathrm{O}_{3}\right)$ in the treatment of acute promyelocytic leukemia: $\mathrm{As}_{2} \mathrm{O}_{3}$ induces NB4 cell apoptosis with downregulation of $\mathrm{Bcl}-2$ expression and modulation of PML-RAR alpha/PML proteins. Blood 88: 1052-1061, 1996.

14. Mathews V, George B, Lakshmi KM, Viswabandya A, Bajel A, Balasubramanian P, Shaji RV, Srivastava VM, Srivastava A and Chandy M: Single-agent arsenic trioxide in the treatment of newly diagnosed acute promyelocytic leukemia: durable remissions with minimal toxicity. Blood 107: 2627-2632, 2006. 
15. Perkins C, Kim CN, Fang G and Bhalla KN: Arsenic induces apoptosis of multidrug-resistant human myeloid leukemia cells that express Bcr-Abl or overexpress MDR, MRP, Bcl-2, or Bcl-x(L). Blood 95: 1014-1022, 2000.

16. Porosnicu M, Nimmanapalli R, Nguyen D, Worthington E, Perkins $\mathrm{C}$ and Bhalla KN: Co-treatment with $\mathrm{As}_{2} \mathrm{O}_{3}$ enhances selective cytotoxic effects of STI-571 against Brc-Abl-positive acute leukemia cells. Leukemia 15: 772-778, 2001.

17. Potin S, Bertoglio J and Bréard J: Involvement of a Rho-ROCK-JNK pathway in arsenic trioxide-induced apoptosis in chronic myelogenous leukemia cells. FEBS Lett 581: 118-124, 2007.

18. Yan H, Wang YC, Li D, Wang Y, Liu W, Wu YL and Chen GQ: Arsenic trioxide and proteasome inhibitor bortezomib synergistically induce apoptosis in leukemic cells: the role of protein kinase Cdelta. Leukemia 21: 1488-1495, 2007.

19. Circu ML and Aw TY: Reactive oxygen species, cellular redox systems, and apoptosis. Free Radic Biol Med 48: 749-762, 2010.

20. Chou WC, Jie C, Kenedy AA, Jones RJ, Trush MA and Dang CV: Role of NADPH oxidase in arsenic-induced reactive oxygen species formation and cytotoxicity in myeloid leukemia cells. Proc Natl Acad Sci USA. 101: 4578-4583, 2004.

21. Stepnik M, Ferlińska M, Smok-Pieniążek A, Gradecka-Meesters D, Arkusz J and Stańczyk M: Assessment of the involvement of oxidative stress and Mitogen-Activated Protein Kinase signaling pathways in the cytotoxic effects of arsenic trioxide and its combination with sulindac or its metabolites: sulindac sulfide and sulindac sulfone on human leukemic cell lines. Med Oncol 29: 1161-1172, 2012.

22. Gorre ME, Mohammed M, Ellwood K, Hsu N, Paquette R, Rao PN and Sawyers CL: Clinical resistance to STI-571 cancer therapy caused by BCR-ABL gene mutation or amplification. Science 293: 876-880, 2001.

23. Radujkovic A, Schad M, Topaly J, Veldwijk MR, Laufs S, Schultheis BS, Jauch A, Melo JV, Fruehauf S and Zeller WJ Synergistic activity of imatinib and 17-AAG in imatinib-resistant CML cells overexpressing BCR-ABL - Inhibition of P-glycoprotein function by 17-AAG. Leukemia 19: 1198-1206, 2005.

24. Li QF, Yan J, Zhang K, Yang YF, Xiao FJ, Wu CT, Wang H and Wang LS: Bortezomib and sphingosine kinase inhibitor interact synergistically to induces apoptosis in $\mathrm{BCR} / \mathrm{ABl}^{+}$cells sensitive and resistant to STI571 through down-regulation Mcl-1. Biochem Biophys Res Commun 405: 31-36, 2011.
25. Wen J, Feng Y, Huang W, Chen H, Liao B, Rice L, Preti HA, Kamble RT, Zu Y, Ballon DJ and Chang CC: Enhanced antimyeloma cytotoxicity by the combination of arsenic trioxide and bortezomib is further potentiated by p38 MAPK inhibition. Leuk Res 34: 85-92, 2010.

26. Canestraro M, Galimberti S, Savli H, Palumbo GA, Tibullo D, Nagy B, Guerrini F, Piaggi S, Cine N, Metelli MR and Petrini M: Synergistic antiproliferative effect of arsenic trioxide combined with bortezomib in HL60 cell line and primary blasts from patients affected by myeloproliferative disorders. Cancer Gene Cytogenet 199: 110-120, 2010.

27. He Y, Yang JM, Wang JM,Z Zhou H, Lü SQ and Hu XX: Synergistic effects of arsenic trioxide and proteasome inhibitor bortezomib on apoptosis induction in Raji cell line. Zhongguo Shi Yan Xue Ye Xue Za Zhi 16: 794-798, 2008 (In Chinese).

28. Ruemmele FM, Dionne S, Qureshi I, Sarma DS, Levy E and Seidman EG: Butyrate mediates Caco-2 cell apoptosis via up-regulation of pro-apoptotic BAK and inducing caspase-3 mediated cleavage of poly-(ADP-ribose) polymerase (PARP). Cell Death Differ 6: 729-735, 1999.

29. Fernandez-Luna JL: Bcr-Abl and inhibition of apoptosis in chronic myelogenous leukemia cells. Apoptosis 5: 315-318, 2000.

30. Bianchini M, De Brasi C, Gargallo P, Gonzalez M, Bengió R and Larripa I: Specific assessment of BCR-ABL transcript overexpression and imatinib resistance in chronic myeloid leukemia patients. Eur J Haematol 82: 292-300, 2009.

31. Wei W, Huang H, Zhao S, Liu W, Liu CX, Chen L, Li JM, $\mathrm{Wu} \mathrm{YL}$ and Yan $\mathrm{H}$ : Alantolactone induces apoptosis in chronic myelogenous leukemia sensitive or resistant to imatinib through $\mathrm{NF}-\mathrm{\kappa B}$ inhibition and $\mathrm{Bcr} / \mathrm{Abl}$ protein deletion. Apoptosis 18: 1060-1070, 2013.

32. Sattler M, Verma S, Shrikhande G, Byrne CH, Pride YB, Winkler T, Greenfield EA, Salgia R and Griffin JD: The BCR/ABL tyrosine kinase induces production of reactive oxygen species in hematopoietic cells. J Biol Chem 275: 24273-24278, 2000.

33. Stein SJ and Baldwin AS: NF- $\kappa B$ suppresses ROS levels in BCR-ABL(+) cells to prevent activation of JNK and cell death. Oncogene 30: 4557-4566, 2011.

34. Naughton R, Quiney C, Turner SD and Cotter TG: Bcr-Abl-mediated redox regulation of the PI3K/AKT pathway. Leukemia 23: 1432-1440, 2009. 